\title{
$\underline{\text { Raw semen concentration directly influences CASA velocity pathways }}$
}

Sonia PARRILLA-HERNANDEZ ${ }^{1 \& 2}$, Stéfan DELEUZE ${ }^{1 \& 2}$, Femke VAN DEN BERGHE ${ }^{1}$, Jérôme PONTHIER $^{1 \& 2}$

${ }^{1}$ Equine Clinic, Veterinary Medicine Faculty; ${ }^{2}$ Center, ULg University of Liège, B-4000, Liège, Belgium

${ }^{2}$ LINALUX-MLS, Centre Européen du Cheval, 18 rue des Champs Elysées, B-5590, Ciney, Belgium

\section{Corresponding author}

E-mail address: sonyaparrilla@gmail.com

Tel: +3283230638

Fax: +3283216790

Address:

LINALUX - Mont-Le-Soie

18, Rue des Champs Elysées

B-5590 CINEY

Belgium 
Physiologically, raw semen characteristics are influenced by stallion and semen conditions [1]. The aim of this study was to investigate how Computer-assisted semen analysis (CASA) results are influenced by raw semen characteristics.

One hundred semen collections (10 collections per stallion, 3 Arabian and 7 sport horses with ages ranging from 3 to 23 years) were analysed. Number of mounts before ejaculation and volume of raw semen were recorded. Spermatozoa concentration was determined using a NucleoCounter SP100 ${ }^{\mathrm{TM}}$ with Chemometec ${ }^{\mathrm{TM}}$ solution (Chemometec ${ }^{\circledR}$, Allerod, Denmark). Motility pathways from semen rediluted to $20 \times 10^{6} \mathrm{spz} / \mathrm{ml}$ for 5 minutes in INRA $96^{\mathrm{TM}}$ (IMV, L'Aigle, France), with dilution ranging from $1 / 3$ to $1 / 40(\mathrm{v} / \mathrm{v})$ were determined using Leja ${ }^{\circledR} 20 \mu \mathrm{m}$ cells in a CASA system (IVOS Version 12.0, with shock excluding option, Hamilton Thorn Research ${ }^{\circledR}$, Beverly, MA, USA). The computer adjustments were: temperature of $37^{\circ} \mathrm{C}, 60$ pictures by second $(60 \mathrm{~Hz})$, spermatozoa size between 4 and 6 pixels. Semen analysis was performed on 10 different frames. Numbers of cells counted by CASA (NCCC) was between 700 and 900 cells per analysis. Velocity Curvilinear (VCL), Velocity Straightline (VSL), Velocity Average Path (VAP) and Straightness (STR) were recorded. Normal distribution of data was tested with Kolmogorov-Smirnov test. Correlations were studied with Pearson or Spearman test when data were normally or not normally distributed, respectively. Statistical significance was set at $\mathrm{p}<0.05$.

Ninety percent of collections were successful at first mount and 5 stallions required 2 mounts or more for a sample to be collected. Correlations between ejaculate volume, concentration and the different CASA parameters are given in Table1.

Number of mounts before ejaculation, which affects seminal plasma production, had an effect on VCL ( $p=0.0464)$. Although significant, this effect did not seem to translate into significant changes in VAP or VSL values. As previously described [1], the number of cells counted for the CASA analysis influenced the motility parameters. However, despite adequate dilution to reach optimal NCCC for the CASA device to work optimally, initial raw semen concentration interfered with VCL, VSL and STR, which could be related to seminal plasma modifications. We observed an influence of the stallion on volume, spermatozoa concentration and all CASA parameters $(\mathrm{p}<0.0001)$, which are highly dependant on each other due to geometrical association of these data. That stallion effect may have interfered with the associations we observed as stallions seem to have specific concentration and motility pathways. More studies, with more replicates, will allow comparing results from a same stallion and further establish the correlations we report here. 
Table 1 Correlations between ejaculate volume, concentration and the different CASA parameters (r values)

\begin{tabular}{|c|c|c|c|c|c|c|}
\hline Parameters & $\frac{\stackrel{0}{\varepsilon}}{\frac{\hat{\varepsilon}}{0}}$ & ن & $\begin{array}{l}\text { પ્ } \\
\mathbf{Z}\end{array}$ & $\frac{n}{n}$ & $\stackrel{J}{>}$ & $\vec{~}$ \\
\hline VAP & $\begin{array}{c}0,2001 \\
*\end{array}$ & $\begin{array}{c}0,233 \\
*\end{array}$ & $\begin{array}{c}-0,2782 \\
* *\end{array}$ & $\begin{array}{c}0,2481 \\
*\end{array}$ & $\begin{array}{c}0,7627 \\
* * * *\end{array}$ & $\begin{array}{c}0,8767 \\
* * * *\end{array}$ \\
\hline VSL & NS & $\begin{array}{c}0,2873 \\
* *\end{array}$ & $\begin{array}{c}-0,2621 \\
*\end{array}$ & $\begin{array}{c}0,6398 \\
* * * *\end{array}$ & $\begin{array}{l}0,42 \\
* * * *\end{array}$ & \\
\hline VCL & NS & NS & $\begin{array}{c}-0,2548 \\
*\end{array}$ & $\begin{array}{c}-0,2918 \\
* *\end{array}$ & & \\
\hline STR & NS & $\begin{array}{c}0,2391 \\
*\end{array}$ & NS & & & \\
\hline NCCC & NS & NS & & & & \\
\hline Conc & $\begin{array}{c}-0,3297 \\
* * *\end{array}$ & & & & & \\
\hline
\end{tabular}

VAP: Velocity Average Pathway; VSL: Velocity Straight Line; VCL: Velocity Curvilinear; STR: Straightness; NCCC: Cells counted by Computer Assisted Sperm Analyser; NS: Not significant; ****: $r$ with p value <0.0001; $* * *$ : $r$ with $p$ value $<0.0005 ; * *: r$ with $p$ value $<0.005 ; *$ : $r$ with $p$ value $<0.05$.

[1] Hoogewijs M, De Vliegher S, De Schauwer C, Govaere J, Smits K, Hoflack G, de Kruif A, Van Soom A. Validation and usefulness of the Sperm Quality Analyzer $V$ equine for equine semen analysis. Theriogenology 2011;75: 189-194.

\section{Comments to the reviewer:}

1) Please indicate physiological significance of the study.

Physiological significance was to test the effect of the stallion, but also of the raw semen characteristics on CASA velocities.

We tried to improve the introduction in a more comprehensive way.

2) Dilution of a semen sample will influence sperm motility as cells have to adapt to the new environment (which could in part explain the effect of concentration [dilution] on motility). How long after dilution was sperm motility evaluated and what was the range in dilution rate?

We improve the Material and Method section

3) Number of mounts will influence seminal plasma volume/compost ion and hence environment of the sperm cell.

We introduced your comment about this effect in the discussion. 